\title{
Endemism and the pelagic larval duration of reef fishes in the eastern Pacific Ocean
}

\author{
Benjamin C. Victor ${ }^{1, *}$, Gerard M. Wellington ${ }^{2}$ \\ ${ }^{1}$ Coralreeffish.com, 4051 Glenwood, Irvine, California 92604, USA \\ ${ }^{2}$ University of Houston, Department of Biology, 4800 Calhoun, Houston, Texas 77204, USA
}

\begin{abstract}
We examined the relationship between pelagic larval duration (PLD) and species range for the wrasses and damselfishes of the eastern Pacific Ocean. This region and these species are particularly appropriate for this analysis, since there is huge variation in the biogeographic range among these reef fishes, from endemics to islands a few kilometers in diameter to pan-Indo-Pacific ranges of $25000 \mathrm{~km}$ or more. Furthermore, this variation in range occurs between pairs of congeners. We found no correlation between the mean (or maximum) PLDs measured from daily otolith increments and biogeographic range, for either family of reef fishes, and even after restricting the analysis to species with sample sizes over 50 individuals. A pairwise comparison of congeners showed, if anything, a significant inverse relationship between larval duration and range. The correlation between mean PLD and maximum PLD was very strong, even for large sample sizes $(r=0.987)$, indicating that mean PLD may be a good proxy measure for maximum PLD. We conclude that, at least within this region and within the limitations of this technique, larval duration appears not to determine species range.
\end{abstract}

KEY WORDS: Reef fish · Biogeography · Pelagic larval duration · Otolith aging

\section{INTRODUCTION}

The tropical eastern Pacific region is remarkable for having a few widely separated island groups and a thin strip of continental shelf. Perhaps as a result of this unusual geography, there is a relatively high rate of endemism among the reef-associated fishes. Unlike comparable reef areas, such as the Caribbean Sea, the biogeography of reef fishes in this region shows a curious pattern of wide-ranging species coexisting with congeners with exceptionally small ranges. This pattern applies across many major reef fish taxa, including the wrasses, damselfishes, angelfishes, and groupers (Allen \& Robertson 1994, Robertson \& Allen 1996). The result is high regional fish diversity, especially relative to total reef area, as well as some of the most restricted geographic ranges known for marine fishes (Rosenblatt 1967, Allen \& Robertson 1994). The

* Order of authorship decided by coin-toss.

E-mail: bvictor2k@gsm.uci.edu pattern of sympatric congeners with vastly differing ranges provides a powerful testing ground for hypotheses explaining the biogeography of reef fishes.

In this study we compare endemics and wide-ranging congeners of wrasses (family Labridae) and damselfishes (family Pomacentridae) and focus on variation in pelagic larval duration (PLD) and its relationship with species range. The time a fish larva spends in the plankton before settling onto a reef is the simplest proxy measure of dispersal ability and few theories on the determinants of range in reef fishes would discount the importance of this feature of early life history. The eastern Pacific region contains reef fishes with some of the longest recorded larval durations as well as some genera with perhaps the largest and smallest geographic ranges known for reef fishes (Victor 1986a). The razorfish genus Xyrichtys, for example, contains $X$. pavo, found from East Africa to Baja California, while $X$. wellingtoni is apparently endemic to Clipperton Atoll in the eastern Pacific, which measures only $4 \mathrm{~km}$ in diameter (at the $50 \mathrm{~m}$ depth contour; Glynn et 
al. 1996). If dispersal ability indeed plays a role in determining range then it would be expected that some relationship would be found between range and PLD.

A variety of other factors can affect dispersal ability, such as larval behavior and distribution (Leis 1991) as well as larval swimming speeds and orientation abilities (Stobutzki \& Bellwood 1994, 1997, Leis \& CarsonEwart 1997). In addition, many other important ecological and physical determinants of range can be proposed. Nevertheless, we focus on PLD because, unlike virtually all the others, it can be easily estimated by otolith aging techniques (Victor 1991). Clearly, an analysis of PLD should be the preliminary step in understanding the biogeography of fishes in this region. Since the otolith aging method has been validated for some members of both wrasses and damselfishes, and we have collected almost all of the eastern Pacific members of these families, we chose to explore the relationship between PLD and biogeographic range for these reef fishes.

\section{METHODS AND MATERIALS}

We surveyed wrasses and damselfishes in the eastern Pacific Ocean from Baja California south, including the Revillagigedos Islands, Clipperton Atoll, Cocos Island, the Galápagos Archipelago, and at the continental shelf in Panamá (Table 1). Collections were made between November 1982 and July 1999, with multiple collections over many years from Baja California, Panamá, and the Galápagos Islands, including collections described in Victor (1986a) and Wellington \& Victor $(1989,1992)$.

Ranges were assigned according to Allen \& Robertson (1994), as well as our own observations. Additional species lists for the island of Malpelo and mainland Ecuador are provided by Rubio et al. (1992), Bearez (1996), and Fernando Rivera of the Estacion Charles Darwin, Galápagos (F. Rivera pers. comm.). For the wrasses, we note the following changes from and additions to ranges reported by Allen \& Robertson (1994): Halichoeres chierchiae to the Galápagos (authors' pers. obs.), H. insularis to Baja California (Gotshall 1998), H. nicholsi to Malpelo and mainland Ecuador (Rubio et al. 1992, F. Rivera pers. comm.), Stethojulis bandanensis to Baja California (authors' pers. obs.) and to Panamá (D. Ross Robertson pers. comm.), Thalassoma lucasanum to mainland Ecuador (F. Rivera pers. comm., authors' pers. obs.), T. purpureum to Galápagos, Cocos, Panamá and Clipperton (Randall 1995, McCosker \& Humann 1996, D. Ross Robertson pers. comm., authors' pers. obs.), T. virens to Baja California (authors' pers. obs.), Xyrichtys mundiceps from the Sea of Cortez (Thomson et al. 1979) and Panamá (Victor et al. in press), $X$. wellingtoni from Clipperton Atoll
(Robertson \& Allen 1996), and X. victori to Cocos (Grove \& Lavenberg 1997). New species include an additional, presumably endemic, Xyrichtys species from the Galápagos (authors' pers. obs.) and a new species of Halichoeres replacing H. melanotis at Cocos Island (D. Ross Robertson pers. comm.).

Among the damselfishes, we note Stegastes acapulcoensis to Galápagos and Malpelo (Rubio et al. 1992, Grove \& Lavenberg 1997, authors' pers. obs.) and S. arcifrons to mainland Ecuador (F. Rivera authors' pers. comm.). We do not include single observations as range extensions (e.g. S. flavilatus to Galápagos; Grove \& Lavenberg 1997).

Range was calculated as the linear surface distance in kilometers between the furthest 2 points of the known world-wide range of the species calculated from the surface of the globe and not from a flat projection. It could be argued that areas should be used, or some weighted mean, taking into account isolation versus contiguous habitats. Nevertheless, we used this simple measure of range, realizing that some subtleties may be lost. The extraordinary variation in biogeographic range for the species we analyzed, almost 4 orders of magnitude, ensures that any real relationship should make itself evident, regardless of the methodology of calculating range.

We also calculated an additional estimate of required dispersal distance: the 'gap traversed'. This distance was measured as the greatest gap within the range without shallow hard substrate, thus taking into account the actual distance larvae would need to travel to maintain their present range. For species found along the coast throughout the region, the largest gap is between Puerto Angel, Mexico and the Golfo de Fonseca of Honduras (about $920 \mathrm{~km}$ on the global projection). The largest gap between islands in the northern group is about the same distance (Clipperton Atoll to the Revillagigedos Islands). For trans-Pacific species, the largest gap was calculated from the Marquesas to the Galápagos (the 'East Pacific Barrier'; about $5000 \mathrm{~km}$ on the global projection).

For pairwise comparisons in the eastern Pacific region, we define a widespread species as one whose range includes Baja California in the north and extends to Peru, Galápagos, or mainland Ecuador in the south or is trans-Pacific. Endemic species are defined as those who are limited to 1 or 2 island groups and/or the Gulf of California (Gulf endemics).

Pelagic larval durations were estimated with the use of the daily otolith increment technique. Otolith increments have been demonstrated directly to be daily in new recruits of representatives of these 2 families of reef fishes and we assume this phenomenon is generally true for other labrid and pomacentrid species and before as well as after settlement. The procedure for 
preparing otoliths and counting increments and calculating PLDs is described for wrasses in Victor (1986a) and for damselfishes in Wellington \& Victor (1989).

\section{RESULTS}

An overall comparison of mean PLD and biogeographic range for eastern Pacific wrasses and dam- selfishes shows no significant relationship between these variables in either family (Fig. 1, Table 2). Refining the analysis by using the recorded maximum PLD in our samples did not improve the relationship (Fig. 2, Table 2). Limiting the analysis to sample sizes over 50 per species did not change the conclusions (Table 2). Despite huge differences in species' ranges, there was no trend to longer larval durations in species with wide biogeographic ranges; in fact, the slope was occasion-

Table 1. Biogeographic range and pelagic larval duration (PLD) of the tropical eastern Pacific wrasses (family Labridae) and damselfishes (family Pomacentridae). All species found in the region are listed. Ranges: WP $=$ western Pacific, BA $=$ Baja California, $\mathrm{RE}=$ Revillagigedos Islands, $\mathrm{CL}=$ Clipperton Atoll, $\mathrm{CO}=$ Cocos Island, PA = Panamá, MA = Malpelo, GA = Galápagos Islands, $\mathrm{EC}=$ Ecuadorian mainland

\begin{tabular}{|c|c|c|c|c|c|c|c|c|c|c|c|c|c|c|c|c|}
\hline \multirow{3}{*}{ Family Labridae } & & \multirow[b]{2}{*}{ WP } & \multirow[b]{2}{*}{$\mathrm{BA}$} & \multicolumn{7}{|c|}{ - Biogeographic range } & \multirow[b]{2}{*}{$\begin{array}{c}\text { Range } \\
(\mathrm{km})\end{array}$} & \multirow{2}{*}{$\begin{array}{c}\text { Larva } \\
\text { Mean PLD } \\
\text { (d) }\end{array}$} & \multirow{2}{*}{$\begin{array}{l}\text { l durati } \\
\text { Min. }\end{array}$} & \multirow{2}{*}{ Max. } & \multirow[b]{2}{*}{$\mathrm{SD}$} & \multirow[b]{2}{*}{$\mathrm{n}$} \\
\hline & & & & $\mathrm{RE}$ & CL & $\mathrm{CO}$ & $\mathrm{PA}$ & MA & GA & $\mathrm{EC}$ & & & & & & \\
\hline & & & & & & & & & & & & & & & & \\
\hline Bodianus & diplotaenia & - & + & + & + & + & + & + & + & + & 7192 & 40 & 31 & 51 & 4.7 & 138 \\
\hline Bodianus & eclancheri & - & - & - & - & - & - & - & + & + & 3308 & 32.3 & 31 & 35 & 2.3 & 3 \\
\hline Decodon & melasma & - & + & $?$ & - & + & $?$ & $?$ & + & + & 4885 & - & - & - & - & - \\
\hline Halichoeres & adustus & - & - & + & - & + & - & - & - & - & 3077 & 33 & 29 & 38 & 2 & 35 \\
\hline Halichoeres & aestuaricola & - & + & - & - & - & + & - & - & - & 4115 & - & - & - & - & - \\
\hline Halichoeres & chierchiae & - & + & + & - & - & + & - & + & - & 4231 & 28.5 & 21 & 38 & 3.5 & 117 \\
\hline Halichoeres & discolor & - & - & - & - & + & - & - & - & - & 6 & 32 & 29 & 38 & 2.4 & 28 \\
\hline Halichoeres & dispilus & - & + & + & - & + & + & $?$ & + & + & 5192 & 39.4 & 30 & 50 & 4 & 147 \\
\hline Halichoeres & insularis & - & + & + & - & - & - & - & - & - & 1269 & 35.5 & 32 & 39 & 1.8 & 20 \\
\hline Halichoeres & malpelo & - & - & - & - & - & - & + & - & - & 2 & - & - & - & - & - \\
\hline Halichoeres & melanotis & - & + & - & - & - & + & - & - & - & 3846 & 35.7 & 31 & 40 & 3.1 & 10 \\
\hline Halichoeres & nicholsi & - & + & + & - & - & + & + & + & + & 4346 & 30.4 & 24 & 38 & 2.8 & 71 \\
\hline Halichoeres & notospilus & - & + & + & - & + & + & + & + & + & 5192 & 37.9 & 29 & 47 & 4.4 & 41 \\
\hline Halichoeres & semicinctus & - & + & - & - & - & - & - & - & - & 1692 & 29.9 & 24 & 36 & 3.6 & 7 \\
\hline Halichoeres & sp. nov. & - & - & - & - & + & - & - & - & - & 6 & 37 & 34 & 40 & 2.6 & 4 \\
\hline Novaculichthys & taeniourus & + & + & + & + & + & + & - & + & - & 25269 & 50.3 & 44 & 57 & 4.4 & 7 \\
\hline Semicossyphus & darwini & - & - & - & - & - & - & - & + & + & 3231 & 37 & 35 & 38 & 1.4 & 2 \\
\hline Semicossyphus & pulcher & - & + & - & - & - & - & - & - & - & 1346 & 37.4 & 34 & 52 & 5.1 & 10 \\
\hline Stethojulis & bandanensis & + & + & + & + & + & + & - & + & - & 17423 & 35 & 31 & 44 & 3.6 & 10 \\
\hline Thalassoma & grammaticum & - & + & + & + & + & + & + & + & - & 3808 & 61.8 & 45 & 94 & 8.3 & 76 \\
\hline Thalassoma & lucasanum & - & + & + & - & + & + & + & + & + & 4115 & 70.2 & 37 & 104 & 11.1 & 721 \\
\hline Thalassoma & purpureum & + & - & - & + & + & + & - & + & - & 23923 & 57.7 & 50 & 62 & 6.7 & 3 \\
\hline Thalassoma & robertsoni & - & - & - & + & - & - & - & - & - & 4 & 58.6 & 45 & 70 & 5.4 & 52 \\
\hline Thalassoma & virens & - & + & + & + & - & - & - & - & - & 1308 & 68.8 & 49 & 96 & 8.2 & 59 \\
\hline Xyrichtys & mundiceps & - & + & - & - & - & + & - & - & - & 3846 & 59.2 & 55 & 67 & 4.3 & 10 \\
\hline Xyrichtys & pavo & + & + & + & $?$ & $?$ & + & - & + & - & 24885 & 51 & 42 & 67 & 6.6 & 14 \\
\hline Xyrichtys & sp. nov. & - & - & - & - & - & - & - & + & - & 100 & 70.7 & 66 & 75 & 4.5 & 3 \\
\hline Xyrichtys & victori & - & - & - & - & + & - & - & + & - & 1038 & 73.7 & 69 & 76 & 2.1 & 3 \\
\hline Xyrichtys & wellingtoni & - & - & - & + & - & - & - & - & - & 4 & 68 & 66 & 70 & 1.6 & 5 \\
\hline \multicolumn{17}{|c|}{ Family Pomacentridae } \\
\hline Abudefduf & concolor & - & - & - & - & + & + & + & + & + & 2308 & 19.7 & 15 & 24 & 2.6 & 24 \\
\hline Abudefduf & declivifrons & - & + & $?$ & - & - & - & - & - & - & 1615 & 21.9 & 17 & 28 & 2.5 & 60 \\
\hline Abudefduf & troschelii & - & + & + & $?$ & + & + & + & + & + & 7115 & 18.1 & 16 & 22 & 1.6 & 11 \\
\hline Azurina & eupalama & - & - & - & - & + & - & - & + & - & 1038 & - & - & - & 1.0 & - \\
\hline Azurina & hirundo & - & + & + & - & - & - & - & - & - & 1654 & - & - & - & - & - \\
\hline Chromis & alta & - & + & + & + & $?$ & + & - & + & - & 4346 & 18.7 & 18 & 20 & 1.2 & 5 \\
\hline Chromis & atrilobata & - & + & + & - & + & + & + & + & + & 5308 & 28.9 & 23 & 38 & 3.1 & 23 \\
\hline Chromis & limbaughi & - & + & - & - & - & - & - & - & - & 692 & 22.8 & 20 & 27 & 1.8 & 15 \\
\hline Hypsypops & rubicundus & - & + & - & - & - & - & - & - & - & 1808 & 20 & 18 & 22 & 2.8 & 2 \\
\hline Microspathodon & bairdii & - & + & + & - & + & + & + & + & + & 4308 & 28.9 & 27 & 30 & 1.4 & 7 \\
\hline Microspathodon & dorsalis & - & + & + & - & + & + & + & + & + & 4308 & 25.9 & 20 & 34 & 4.5 & 31 \\
\hline Nexilosus & latifrons & - & - & - & - & - & - & + & + & + & 3115 & 29.2 & 28 & 33 & 1.8 & 10 \\
\hline Stegastes & acapulcoensis & - & + & + & - & + & + & + & + & + & 4808 & 22.7 & 17 & 29 & 2.9 & 233 \\
\hline Stegastes & arcifrons & - & - & - & - & + & - & + & + & + & 1269 & 29.8 & 20 & 35 & 2.5 & 103 \\
\hline Stegastes & baldwini & - & - & - & + & - & - & - & - & - & 4 & 26 & 23 & 29 & 1.4 & 52 \\
\hline Stegastes & flavilatus & - & + & + & - & + & + & - & - & + & 4500 & 25.8 & 20 & 39 & 3.8 & 250 \\
\hline Stegastes & leucorus beebei & - & - & - & - & + & + & + & + & - & 1769 & 33.4 & 27 & 36 & 2.1 & 40 \\
\hline Stegastes & leucorus leucorus & - & + & + & - & - & - & - & - & - & 1269 & 34 & 31 & 47 & 3.2 & 30 \\
\hline Stegastes & rectifraenum & - & + & - & - & - & - & - & - & - & 923 & 21.5 & 17 & 25 & 2 & 51 \\
\hline Stegastes & redemptus & - & + & + & - & - & - & - & - & - & 692 & 32.3 & 29 & 35 & 1.7 & 15 \\
\hline
\end{tabular}


ally negative which, if significant, would represent a reduction in PLD with increasing range (e.g. for damselfish PLD vs range, and in both analyses of wrasse
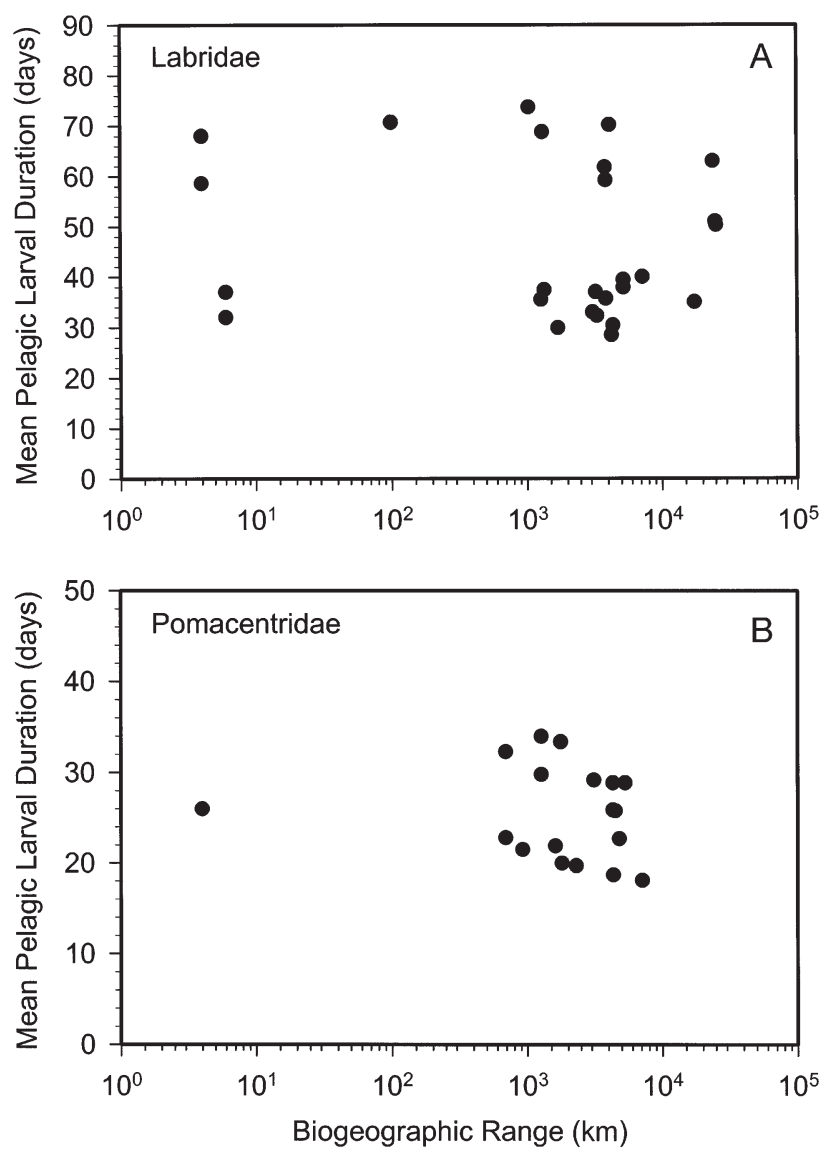

Fig. 1. Relationship between biogeographic range and mean pelagic larval duration (PLD) for (A) eastern Pacific labrid and

(B) pomacentrid reef fishes species with sample sizes over 50). Use of the 'gap traversed' instead of overall range also did not improve the relationship (Table 2). The most derived analysis, the combined families' maximum PLD of samples over 50 versus gap traversed, does show a weak trend to a positive relationship. However, combining families introduces a bias in that several endemic wrasse species with long larval lives were not included (e.g. the razorfishes) while the short-lived damselfishes were included. Clearly, when families (or sometimes genera) are combined in an uneven fashion any kind of artifactual relationship can be introduced.

A more precise comparison can be made for closely related pairs of congeners with different-sized ranges. The pairwise comparisons can be made for 2 different forms of congeneric biogeography. One is sympatry, where 2 closely related species coexist in a locality and, for some reason, the endemic does not disperse or survive elsewhere while its congener is widespread. All other things held equal, a dispersal-based hypothesis to explain this pattern would be a short PLD for the endemic and a relatively long PLD for the widespread species.

The second pattern is allopatry, where there is a widespread congener and an endemic congener that replaces the widespread species in an isolated locality. The origin of this pattern is presumably the genetic divergence of an isolated local population with subsequent restricted gene flow between the geminates, as well as some barrier to recolonization by the widespread species and a barrier to spread by the endemic. All other things held equal, a dispersal-based hypothesis to explain this pattern would be a short PLD for the endemic and a moderate PLD for the widespread species, with the short PLD preventing dispersal away from the locality by the endemic, and the moderate

Table 2. Regression analyses of PLDs and range for labrids and pomacentrids (Poma); using mean, maximum, and maximum with sample size over 50 for PLD and simple range and 'gap traversed' as measures of range. The bottom row represents the results of regression of the pairwise comparisons listed in Table 3 using mean PLD, maximum PLD, and maximum PLD with each member of the pair having sample sizes over 30 (therefore total $n>60$ )

\begin{tabular}{|c|c|c|c|c|c|c|c|}
\hline & \multicolumn{2}{|c|}{ Mean PLD (d) } & \multicolumn{2}{|c|}{ Max. PLD (d) } & \multicolumn{3}{|c|}{ Max. PLD $(\mathrm{n}>50)(\mathrm{d})$} \\
\hline & Labrid & Poma & Labrid & Poma & Labrid & Poma & Combined \\
\hline Range (km) & $\begin{array}{c}0.09 \times 10^{-3} \\
\mathrm{p}=0.83 \\
\mathrm{r}^{2}=0.002 \\
\mathrm{n}=26\end{array}$ & $\begin{array}{c}-0.74 \times 10^{-3} \\
\mathrm{p}=0.25 \\
\mathrm{r}^{2}=0.083 \\
\mathrm{n}=18\end{array}$ & $\begin{array}{c}0.15 \times 10^{-3} \\
\mathrm{p}=0.78 \\
\mathrm{r}^{2}=0.003 \\
\mathrm{n}=26\end{array}$ & $\begin{array}{c}-0.52 \times 10^{-3} \\
\mathrm{p}=0.55 \\
\mathrm{r}^{2}=0.023 \\
\mathrm{n}=18\end{array}$ & $\begin{array}{c}-5.15 \times 10^{-3} \\
\mathrm{p}=0.3 \\
\mathrm{r}^{2}=0.176 \\
\mathrm{n}=8\end{array}$ & $\begin{array}{l}0.71 \times 10^{-3} \\
\mathrm{p}=0.5 \\
\mathrm{r}^{2}=0.123 \\
\mathrm{n}=6\end{array}$ & $\begin{array}{c}0.62 \times 10^{-3} \\
\mathrm{p}=0.87 \\
\mathrm{r}^{2}=0.002 \\
\mathrm{n}=14\end{array}$ \\
\hline Gap traversed $(\mathrm{km})$ & $\begin{array}{c}0.04 \times 10^{-3} \\
\mathrm{p}=0.98 \\
\mathrm{r}^{2}<0.001 \\
\mathrm{n}=26\end{array}$ & $\begin{array}{c}1.38 \times 10^{-3} \\
\mathrm{p}=0.69 \\
\mathrm{r}^{2}=0.01 \\
\mathrm{n}=18\end{array}$ & $\begin{aligned} 0.23 & \times 10^{-3} \\
\mathrm{p} & =0.93 \\
\mathrm{r}^{2} & <0.001 \\
\mathrm{n} & =26\end{aligned}$ & $\begin{array}{c}2.68 \times 10^{-3} \\
\mathrm{p}=0.56 \\
\mathrm{r}^{2}=0.021 \\
\mathrm{n}=18\end{array}$ & $\begin{array}{c}-12.1 \times 10^{-3} \\
\mathrm{p}=0.7 \\
\mathrm{r}^{2}=0.024 \\
\mathrm{n}=8\end{array}$ & $\begin{array}{l}6.27 \times 10^{-3} \\
\mathrm{p}=0.13 \\
\mathrm{r}^{2}=0.473 \\
\mathrm{n}=6\end{array}$ & $\begin{array}{c}19.52 \times 10^{-3} \\
\mathrm{p}=0.3 \\
\mathrm{r}^{2}=0.09 \\
\mathrm{n}=14\end{array}$ \\
\hline $\begin{array}{l}\text { Pairwise comparison } \\
\text { (families combined) }\end{array}$ & \multicolumn{2}{|c|}{$\begin{array}{c}\text { Slope }=0.70, \text { intercept }=7.6 \\
\mathrm{p}<0.001 \\
\mathrm{r}^{2}=0.73 \\
\mathrm{n}=33\end{array}$} & \multicolumn{2}{|c|}{$\begin{array}{c}\text { Slope }=0.77, \text { intercept }=7.6 \\
\mathrm{p}<0.001 \\
\mathrm{r}^{2}=0.74 \\
\mathrm{n}=33\end{array}$} & \multicolumn{3}{|c|}{$\begin{array}{c}\text { Slope }=1.04, \text { intercept }=-1.2 \\
\mathrm{p}<0.002 \\
\mathrm{r}^{2}=0.81 \\
\mathrm{n}=8\end{array}$} \\
\hline
\end{tabular}


PLD sufficient for some dispersal but not enough to recolonize the isolated locality.

We collected a set of congeneric pairs for this comparison (Table 3). Many of the PLDs for sympatric pairs of congeners were compared for collections from the same site and the same time, to avoid any complications of geographic and seasonal variation in PLD. Regional and seasonal variations in PLD have been documented to occur at Baja California for both wrasses and damselfishes; however little variation has been detected in the rest of the region (Wellington \& Victor 1992). For sympatric species pairs, we obtained pairwise comparisons with mostly simultaneous collections ( 7 wrasse pairs, 2 damselfish pairs) and pairs that we could not collect from the same site (11 wrasse pairs, 5 damselfish pairs). For this latter group we compared from the closest region and time that was possible. Some species were used more than once in the pair comparisons.

Allopatric species pairs were less common (4 wrasse pairs, 4 damselfish pairs), especially since so many
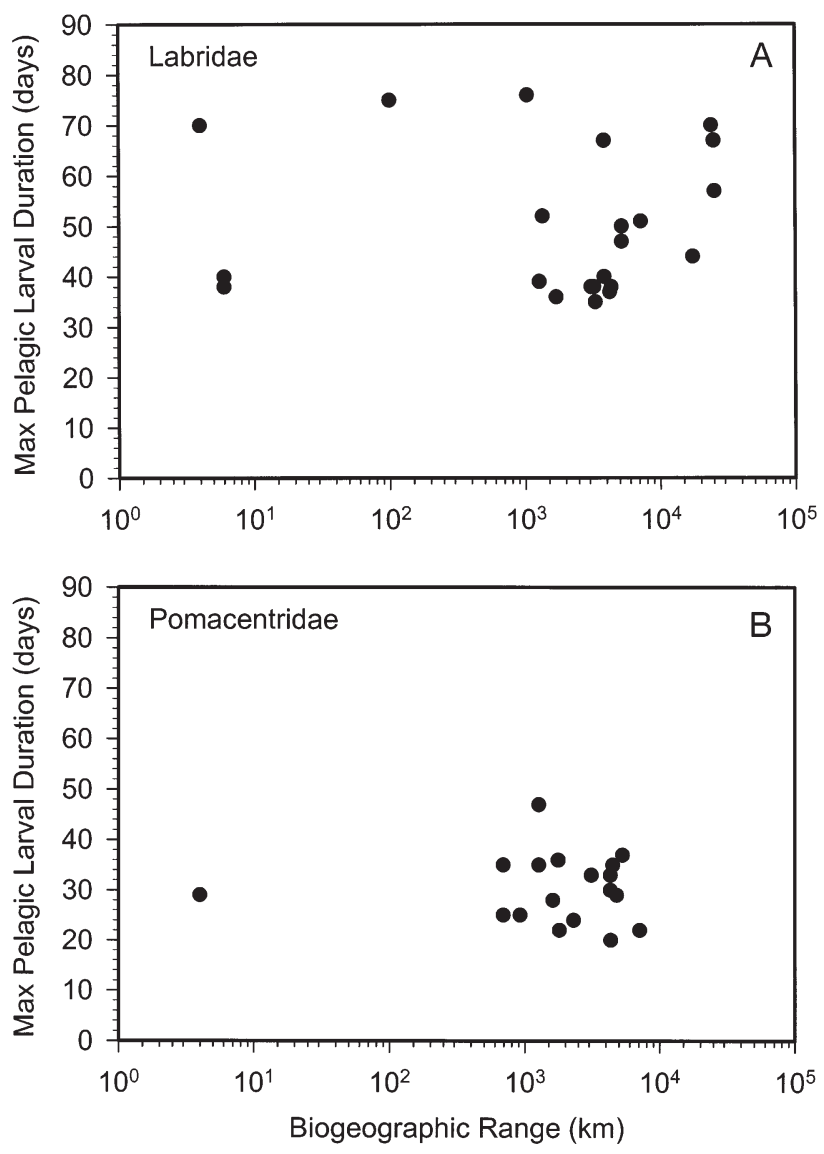

Fig. 2. Relationship between biogeographic range and maximum PLD for (A) eastern Pacific labrid and (B) pomacentrid reef fishes recently recorded range extensions have reduced the observed rate of allopatry. Some pairs are obvious geminates, e.g. Thalassoma robertsoni and T. lucasanum, and Chromis limbaughi and C. alta, while others are only presumed. By definition, allopatric pairs could not be compared from the same collections, and therefore samples of the widespread species of the pair were collected when possible from about the same latitude.

The mean PLD of the appropriate sample of the endemic species was plotted against the mean PLD of the corresponding sample for the widespread congener (Fig. 3). If there were a tendency for endemics to have shorter larval lives, then the resulting plot should have a slope more than 1 and/or an intercept greater

Table 3. List of endemic and widespread species pairs of eastern Pacific labrids and pomacentrids and the sites of collection for a pairwise comparison of PLD. Site abbreviations as in Table 1

\begin{tabular}{|c|c|}
\hline Species pair (endemic $\times$ widespread) & $\begin{array}{l}\text { Location of } \\
\text { collections }\end{array}$ \\
\hline \multicolumn{2}{|l|}{ Sympatric pairs } \\
\hline Halichoeres adustus $\times H$. dispilus & $\mathrm{CO}$ \\
\hline$H$. discolor $\times H$. dispilus & $\mathrm{CO}$ \\
\hline Thalassoma robertsoni $\times T$. grammaticum & CL \\
\hline$T$. virens $\times T$. grammaticum & CL \\
\hline T. virens $\times T$. lucasanum & BA \\
\hline Xyrichtys victori $\times X$. pavo & GA \\
\hline Xyrichtys sp. nov. $\times$ X. pavo & GA \\
\hline Stegastes rectifraenum $\times S$. flavilatus & BA \\
\hline$S$. rectifraenum $\times S$. acapulcoensis & BA \\
\hline \multicolumn{2}{|l|}{ Sympatric pairs (different collection sites) } \\
\hline Halichoeres adustus $\times H$. chierchiae & $\mathrm{CO} / \mathrm{PA}$ \\
\hline$H$. adustus $\times H$. melanotis & $\mathrm{CO} / \mathrm{PA}$ \\
\hline H. adustus $\times H$. nicholsi & $\mathrm{CO} / \mathrm{PA}$ \\
\hline$H$. adustus $\times H$. notospilus & $\mathrm{CO} / \mathrm{PA}$ \\
\hline$H$. discolor $\times H$. notospilus & $\mathrm{CO} / \mathrm{PA}$ \\
\hline$H$. insularis $\times H$. chierchiae & $\mathrm{RE} / \mathrm{PA}$ \\
\hline$H$. insularis $\times H$. dispilus & $\mathrm{RE} / \mathrm{CO}$ \\
\hline$H$. insularis $\times H$. nicholsi & RE/PA \\
\hline$H$. insularis $\times H$. notospilus & $\mathrm{RE} / \mathrm{PA}$ \\
\hline Halichoeres sp. nov. $\times$ H. notospilus & $\mathrm{CO} / \mathrm{PA}$ \\
\hline Xyrichtys wellingtoni $\times X$. pavo & CL/GA \\
\hline Stegastes arcifrons $\times S$. acapulcoensis & GA/PA \\
\hline S. leucorus beebei $\times S$. acapulcoensis & GA/PA \\
\hline$S$. leucorus leucorus $\times S$, acapulcoensis & $\mathrm{RE} / \mathrm{BA}$ \\
\hline$S$. leucorus leucorus $\times S$. flavilatus & $\mathrm{RE} / \mathrm{BA}$ \\
\hline$S$. redemptus $\times S$. flavilatus & $\mathrm{RE} / \mathrm{PA}$ \\
\hline \multicolumn{2}{|l|}{ Allopatric pairs } \\
\hline Halichoeres discolor $\times H$. nicholsi & $\mathrm{CO} / \mathrm{PA}$ \\
\hline Halichoeres sp. nov. $\times H$. melanotis & $\mathrm{CO} / \mathrm{PA}$ \\
\hline Thalassoma robertsoni $\times T$. lucasanum & CL/PA \\
\hline T. virens $\times T$. purpureum & $\mathrm{CL} / \mathrm{GA}$ \\
\hline Chromis limbaughi $\times$ C. alta & $\mathrm{BA} / \mathrm{GA}$ \\
\hline Stegastes baldwini $\times S$. acapulcoensis & CL/PA \\
\hline$S$. baldwini $\times S$. flavilatus & CL/PA \\
\hline S. redemptus $\times S$. acapulcoensis & $\mathrm{RE} / \mathrm{PA}$ \\
\hline
\end{tabular}




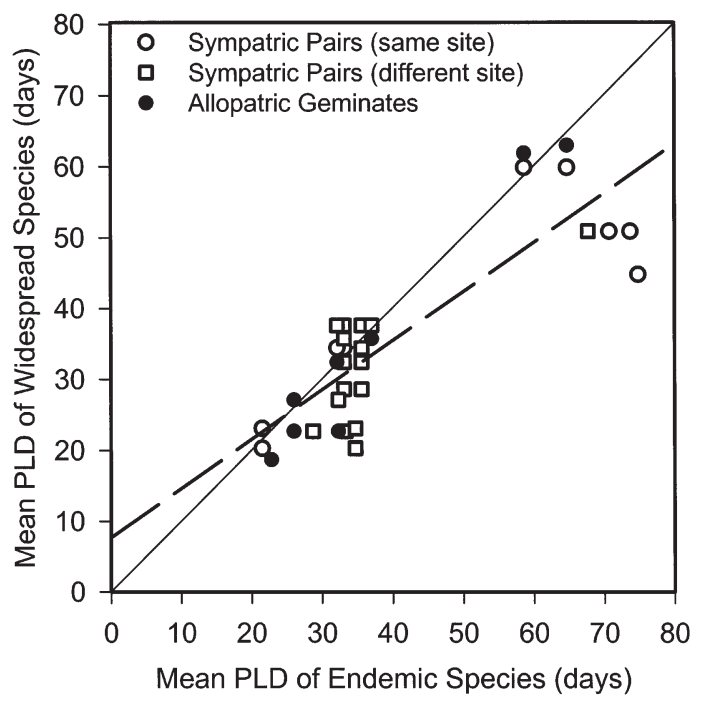

Fig. 3. Pairwise comparisons of mean PLD for paired endemic versus widespread congeners of the eastern Pacific labrid and pomacentrid reef fishes listed in Table 3. Not all individuals listed in Table 1 for the relevant species are utilized: only subsets from simultaneous collections or those paired in time and region. The solid line represents the line of unity (equal PLDs); the broken line represents the regression line for the 3 sets combined: PLD (widespread) $=0.7$ PLD $($ endemic $)+7.6 \mathrm{~d}$ $\left(\mathrm{p}<0.001, \mathrm{r}^{2}=0.73, \mathrm{n}=33\right)$

than 0 (an intercept greater than 0 in the absence of a slope differing from 1 would be obtained if the widespread species had a constant additional larval life regardless of mean PLD). If there were no overall difference, then the slope should be no different from 1 and the intercept should be 0 . This method assesses whether there is a general trend, rather than focusing on specific comparisons. We used this method in place of detailed pairwise analysis of variance, since the data were heterogeneous, often with small and varying sample sizes. Furthermore, some significant species differences were to be expected in the complex groupings we used, and it would be difficult to interpret relative numbers of shorter versus longer larval durations in the pairwise comparisons.

The slope was, in fact, significantly less than 1, indicating some tendency for endemics to have longer larval durations than widespread species (slope of $0.7, \mathrm{p}<$ $0.001, \mathrm{r}^{2}=0.73$; slope significantly different from $1, \mathrm{p}<$ 0.05) (Fig. 3, Table 2). The intercept was at $7.6 \mathrm{~d}$ (significantly greater than $0, \mathrm{p}<0.03$ ), although this would have more meaning if the slope were 1 or greater. When maximum PLD is used, the slope is still significantly less than 1 ( $p<0.05)$, and the intercept becomes no different from 0 . This counter-intuitive finding (slope less than 1) is likely driven by the presence of several endemics who have particularly long larval lives, such as Xyrichtys species. When these species are removed by requiring a sample size of at least 30 per species, the slope reverts to 1.04 and is not significantly different from 1 and the intercept gets close to 0 (Table 2). These results indicate that even for matched pairs of species, there is clearly no tendency for widespread species to have longer larval durations.

\section{DISCUSSION}

There is, at present, no coherent theory explaining the complex biogeographic patterns exhibited by eastern Pacific reef fishes. Historically, vagility, or dispersal ability, has been postulated as the primary determinant of range for marine organisms with pelagic larvae (e.g. Scheltema 1968). Vagility is determined by a number of factors. The most obvious components of vagility comprise PLD, swimming ability, and larval behavior and ecology (Leis 1991). In addition, the ability to delay larval metamorphosis, remain pelagic as a juvenile, or even re-enter the pelagic realm as an adult directly affect vagility (e.g. Robertson \& Foster 1982). Other independent factors, including local abundance, spawning frequency and seasonality, and the size of adults could also have an influence on dispersal rates. Alternatively, it has been suggested that ecological constraints, perhaps competition or presence of specific habitats, determine which species colonize which sites, regardless of their ability to get there. There even may be specific ecological requirements for larvae, independent of the ability of adults to persist in a habitat (Leis 1986). Unfortunately, there is little evidence for any unifying hypothesis and the more data are gathered, the less clear the picture becomes.

Our survey of eastern Pacific reef fish biogeography showed that PLDs, as inferred from otolith counts, are not correlated with species range in this region. This finding does not directly demonstrate that dispersal ability does not determine range, since larval duration is only a proxy measure of dispersal ability. A variety of complicating issues could hamper the analysis. It could be that the otolith aging technique is inappropriate for measuring larval durations and some as yet undetected artifact is producing increments on larval otoliths. Alternatively, sampling error may hide the true larval duration (McCormick 1994). It may be necessary to sample sufficiently intensively to discern the degree to which some few larvae can delay metamorphosis, for it is these larvae that would colonize new areas (Victor 1986b, Cowen 1991, McCormick 1994). It has been pointed out that maximum larval durations should be used when dealing with evolutionary or zoogeographic questions (Leis 1991). When we limited the analysis to the maximum PLD for those species for 
which we had large samples (over 50), there was still no significant relationship with range. Using averages, however, is not as reckless as it may first appear. Indeed, the mean may be a good indicator of the maximum since there is a strong correlation between mean PLD and maximum PLD regardless of sample size: for our data set the correlation coefficient gets stronger with increasing sample size; $r=0.951$ overall, $r=0.984$ for samples over 30, and $r=0.987$ for samples over 50 (Fig. 4). It also should be noted that the rare maximum may not be biologically relevant, since colonization requires survival to adulthood of sufficient numbers to establish a breeding population and the rare solitary individual that occasionally arrives would never be able to colonize.

Geographic and seasonal variations in larval duration could easily compromise the accuracy of PLD estimates, although studies of geographic variation in other areas have shown at most only minor differences in average PLDs (but see Victor 1986a for Hawaii vs western Pacific and McCormick 1994 for goatfishes). In the past we have found 1 significant anomaly: a regional and seasonal difference in PLD in Baja California (Wellington \& Victor 1992, unpubl.). In this study, we have tried to take most of these factors into account by repeated sampling, using large sample sizes where possible, and controlling for known geographic variation. The clear absence of any apparent relationship between our estimates of PLD and range argues that some methodological shortcoming is not responsible for the lack of a correlation.

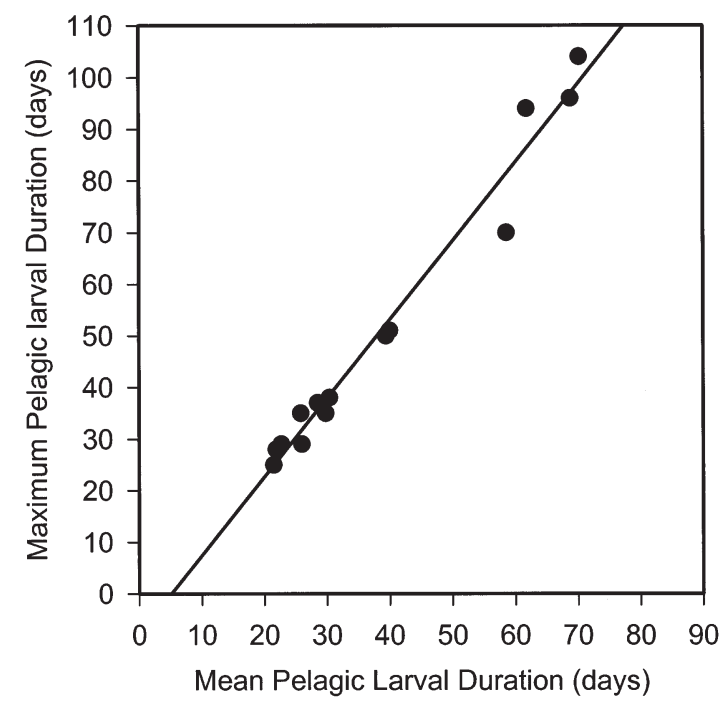

Fig. 4. Relationship between mean and maximum PLD for eastern Pacific labrid and pomacentrid reef fishes with sample sizes greater than 50 individuals. The solid line represents the regression line
It is certainly possible that length of larval life is not the primary determinant of dispersal ability. Recent studies have shown that reef fish larvae have strong swimming abilities and orientation abilities (at least during later stages; Leis et al. 1996, Leis \& CarsonEwart 1997), and these characteristics may affect how far larvae disperse from their natal region. Indeed, at least 1 recent study has shown puzzling genetic heterozygosity between reef fish populations within a single island group, suggesting that long-distance pelagic dispersal may not be automatic in reef fish with longlived larval stages (Planes et al. 1998).

Any radical reinterpretation of the long-distance dispersal abilities of reef fishes must, however, take into account the vast ranges of some reef fish species. Furthermore, the documented arrival of vagrants from distant regions clearly indicates that many reef fish species do have long-distance dispersal abilities, even within the short period of recent scientific investigations. Crossing of the eastern Pacific Barrier, the widest tract of tropical ocean without stepping stones, is occasionally observed. A number of Central Pacific reef fish species have recently been reported in the Galápagos Islands and Clipperton Atoll, usually associated with the El Niño-Southern Oscillation event (Merlen 1988, McCosker \& Humann 1996, Robertson \& Allen 1996, Grove \& Lavenberg 1997). This phenomenon is not limited to fishes: Lessios et al. $(1996,1998)$ have documented the recent invasion of the western Pacific sea urchin Echinothrix diadema at several sites in the eastern Pacific. Fish larvae of some of the genera in our study have been captured both in the middle of the eastern Pacific Barrier (Thalassoma; Leis 1983), as well as $400 \mathrm{~km}$ east of the Galápagos Islands (Halichoeres, Thalassoma, Xyrichtys, Stegastes; Victor 1987). Clearly, these fish larvae do disperse far into the open ocean in great numbers, sufficient to show up in small plankton nets.

Although PLD does not correlate with range within the eastern Pacific region, there is certainly some overall relationship between ocean-wide dispersal and PLD. The species that cross the Pacific Ocean to Hawaii and the eastern Pacific tend to have long PLDs (e.g. Victor 1986a). Generally, species that cross the Pacific come from families with long-lived larvae such as labrids (wrasses), acanthurids (surgeonfishes), and muraenids (moray eels), while families with shorterlived larvae do not cross, e.g. pomacentrids (damselfishes), haemulids (grunts and relatives), and all but 1 lutjanid (snappers) (Leis 1984, Allen \& Robertson 1994, Robertson \& Allen 1996). Beyond this simple tendency, no relationship appears to exist: species with long PLDs can be endemic to a single island and, within the region, the correlation between measured PLD and range is non-existent. 
Acknowledgements. This work was supported by grants from the National Geographic Society \#4161-89, \#5308-92 and NOAA- NA56GP0382-02 to G.M.W. Chris Caldow, Laura Guttierez, Brian Phillips, Brad Tilton and many others helped in the field, made collections in Baja California, and extracted otoliths in the laboratory. Fernando Rivera and D. Ross Robertson provided invaluable comments. We thank the Galápagos National Park Service and the Charles Darwin Research Station for granting permission to work in the Galápagos Islands. In addition, we thank the Government of Costa Rica for permission to visit Isla del Coco (Cocos Island), and the Smithsonian Tropical Research Institute for facilitating the field work in Panamá.

\section{LITERATURE CITED}

Allen GR, Robertson DR (1994) Fishes of the tropical eastern Pacific. University of Hawaii Press, Honolulu

Bearez P (1996) Lista de los peces marinos del Ecuador continental. Rev Biol Trop 44:731-741

Cowen RK (1991) Variation in the planktonic larval duration of the temperate wrasse Semicossyphus pulcher. Mar Ecol Prog Ser 69:9-15

Glynn PW, Vernon JEN, Wellington GM (1996) Clipperton Atoll (eastern Pacific): oceanography, geomorphology, reef-buiding coral ecology and biogeography. Coral Reefs 15:71-99

Gotshall DW (1998) Sea of Cortez marine animals. Sea Challengers, Monterey

Grove JS, Lavenberg RJ (1997) The fishes of the Galápagos Islands. Stanford University Press, Stanford

Leis JM (1983) Coral reef fish larvae (Labridae) in the east Pacific Barrier. Copeia 1983(3):826-828

Leis JM (1984) Larval fish dispersal and the East Pacific Barrier. Oceanogr Trop 19:181-192

Leis JM (1986) Ecological requirements of Indo-Pacific larval fishes: a neglected zoogeographic factor. In: Uyeno T, Arai R, Taniuchi T, Matsura K (eds) Proceedings of the second international conference on Indo-Pacific fishes. Ichthyological Society of Japan, Tokyo, p 759-766

Leis (1991) The pelagic phase of coral reef fishes: larval biology of coral reef fishes. In: Sale PF (ed) The ecology of fishes on coral reefs. Academic Press, San Diego, p 183-230

Leis JM, Carson-Ewart BM (1997) In situ swimming speeds of the late pelagic larvae of some Indo-Pacific coral-reef fishes. Mar Ecol Prog Ser 159:165-174

Leis JM, Sweatman HPA, Reader SE (1996) What the pelagic stages of coral reef fishes are doing out in blue water: daytime field observations of larval behavioural capabilities. Mar Freshw Res 47:401-411

Lessios HA, Kessing BD, Wellington GM, Graybeal A (1996) Indo-Pacific echinoids in the tropical eastern Pacific. Coral Reefs 15:133-142

Lessios HA, Kessing BD, Robertson DR (1998) Massive gene flow across the world's most potent marine biogeographic barrier. Proc R Soc Lond B 265:583-588

McCormick MI (1994) Variability in age and size at settlement of the tropical goatfish Upeneus tragula (Mullidae) in the

Editorial responsibility: Charles Birkeland (Contributing Editor), Mangilao, Guam northern Great Barrier Reef lagoon. Mar Ecol Prog Ser 103:1-15

McCosker JE, Humann PH (1996) New records of Galápagos fishes. Not Galápagos 56:18-22

Merlen G (1988) Two new butterflyfish records from Wenman Island. Not Galápagos 46:8-9

Planes S, Parroni M, Chauvet C (1998) Evidence of limited gene flow in three species of coral reef fishes in the lagoon of New Caledonia. Mar Biol 130:361-368

Randall JE (1995) On the validity of the eastern Pacific labrid fishes Thalassoma grammaticum Gilbert and T. virens Gilbert. Bull Mar Sci 56(2):670-675

Robertson DR, Allen GR (1996) Zoogeography of the shorefish fauna of Clipperton Atoll. Coral Reefs 15:121-131

Robertson DR, Foster SA (1982) Off-reef emigration of young adults of the labrid fish Epibulus insidiator. Copeia 1982: 227-229

Rosenblatt RH (1967) The zoogeographic relationships of the marine shore fishes of tropical America. Stud Trop Oceanogr 5:579-592

Rubio R, Suarez A, Estupinan F, Henao W, Vargas B (1992) Los recursos ictiologicos de la Isla Malpelo (Colombia). I. Una revision de su conocimiento y nuevos reportes para la ictiofauna de la isla. Comision Colombiana de Oceanografia, VIII Seminario Nacional de las Ciencias y las Tecnologias del Mar y Congreso Centroamerica y del Caribe en Ciencias del Mar; Memorias Tomo II:642-658

Scheltema RS (1968) Dispersal of larvae by equatorial ocean currents and its importance to the zoogeography of shoalwater tropical species. Nature 217:1159-1162

Stobutzki IC, Bellwood DR (1994) An analysis of the sustained swimming abilities of pre- and post-settlement coral reef fishes. J Exp Mar Biol Ecol 175:275-286

Stobutzki IC, Bellwood DR (1997) Sustained swimming abilities of the late pelagic stages of coral reef fishes. Mar Ecol Prog Ser 149:35-41

Thomson DA, Findley LT, Kerstich AN (1979) Reef fishes of the Sea of Cortez. John Wiley and Sons, New York

Victor BC (1986a) Duration of the planktonic larval stage of one hundred species of Pacific and Atlantic wrasses (Family Labridae). Mar Biol 90:317-326

Victor BC (1986b) Delayed metamorphosis with reduced larval growth in a coral reef fish (Thalassoma bifasciatum). Can J Fish Aquat Sci 43:1208-1213

Victor BC (1987) Growth, dispersal, and identification of planktonic labrid and pomacentrid reef-fish larvae in the eastern Pacific Ocean. Mar Biol 95:145-152

Victor BC (1991) Settlement strategies and biogeography of reef fishes. In: Sale PF (ed) The ecology of fishes on coral reefs. Academic Press, San Diego, p 231-260

Victor BC, Wellington GM, Caldow C (in press) A review of the razorfishes (Perciformes: Labridae) of the eastern Pacific Ocean. Rev Biol Trop

Wellington GM, Victor BC (1989) Planktonic larval duration of one hundred species of Pacific and Atlantic damselfishes (Pomacentridae). Mar Biol 101:557-567

Wellington GM, Victor BC (1992) Regional differences in duration of the planktonic larval stage of reef fishes in the eastern Pacific Ocean. Mar Biol 113:491-498

Submitted: July 22, 1999; Accepted: March 1, 2000

Proofs received from author(s): September 27, 2000 